Finance and Economics Discussion Series

Divisions of Research \& Statistics and Monetary Affairs

Federal Reserve Board, Washington, D.C.

\title{
Precautionary Savings Motives and Tax Efficiency of Household Portfolios: An Empirical Analysis
}

\section{Gene Amromin}

2005-01

NOTE: Staff working papers in the Finance and Economics Discussion Series (FEDS) are preliminary materials circulated to stimulate discussion and critical comment. The analysis and conclusions set forth are those of the authors and do not indicate concurrence by other members of the research staff or the Board of Governors. References in publications to the Finance and Economics Discussion Series (other than acknowledgement) should be cleared with the author(s) to protect the tentative character of these papers. 


\title{
Precautionary Savings Motives and Tax Efficiency of Household Portfolios: An Empirical Analysis*
}

\author{
Gene Amromin \\ Board of Governors of the Federal Reserve System
}

Tax efficiency is the dominant consideration in theoretical portfolio models that allow for both taxable and tax-deferred accounts (TDAs). Investors are advised to locate higher-tax assets in their tax-deferred accounts, which in the Unites States commonly translates into "holding bonds inside TDAs and holding equities outside." Yet, observed portfolio allocations are not taxefficient. This paper empirically evaluates the predictions of a recent model designed to bridge the existing gap by explicitly incorporating uninsurable labor income risk and limited accessibility of TDA assets in household decisions [Amromin, 2003]. Together, these elements create tension between household's desire to maintain tax-efficient allocations and its concern over the need to make costly TDA withdrawals in the event of bad income draws. This leads some borrowing-constrained households facing labor income risk and TDA access penalties to forgo tax-efficiency in favor of allocations that provide more liquidity in bad income states - an outcome labeled as "precautionary portfolio choice”. The empirical results based on householdlevel portfolio data from the Survey of Consumer Finances provide evidence that both the choice of whether to hold a tax-efficient portfolio and the degree of portfolio tax-inefficiency are related to the presence and severity of precautionary motives.

JEL Classification Codes: D12, G11, and H24.

\footnotetext{
* This paper is based on Chapter 2 of my doctoral dissertation. I would like to thank Lars Hansen, John Heaton, Anil Kashyap, and Annette Vissing-Jorgensen for their invaluable guidance and advice. Thanks are also due to participants at the Economic Dynamics working group at the University of Chicago, the 2002 NBER Summer Institute, and the 2003 WFA meetings. I am grateful to the University of Chicago and the National Science Foundation for generous financial support. I am responsible for all remaining errors. The views presented here are mine alone and do not necessarily represent those of the Federal Reserve Board or its staff.
} 


\section{Introduction}

Portfolio choices of individual investors appear mysterious to economists. This paper focuses on one of the mysteries: the pervasive tax-inefficiency of asset allocations of households investing in taxable and tax-deferred accounts (TDAs). Understanding this decision is particularly important in light of the active debate over whether individuals should be given more control over their Social Security savings. Some studies estimate that tax-inefficient allocations result in sizable welfare losses. ${ }^{1}$ I offer a somewhat different perspective by focusing on the empirical investigation of the underlying reasons for such "irrational" behavior. This paper provides evidence that losses from tax-inefficiency can be at least partially regarded as costs borne by liquidity-constrained households to protect themselves against exposure to uninsurable labor income risk.

In recent years, individually managed retirement accounts have become one of the main avenues for household saving in the United States. ${ }^{2}$ Such accounts are granted favorable tax treatment and typically allow accumulation of retirement assets at pre-tax rates of return. However, to ensure that TDA savings are used for their intended purpose, this powerful tax incentive is counterbalanced by a variety of restrictions on accessibility of TDA assets. Consequently, the existence of TDAs, which differ both in terms of their tax treatment and degree of liquidity, makes household investment choice much more complex. In addition to choosing between broad asset classes such as stocks and bonds, households must also decide on how much of each asset class to locate in each of the two investment habitats. This joint portfolio decision became known as the asset location and allocation problem [Shoven 1999].

This problem has a clear-cut and intuitive solution, whose origins date back to the pioneering work of Black [1980] and Tepper [1981] on optimal portfolio choices of corporations interested in funding their defined-benefit pension plans. The solution is based on exploiting arbitrage opportunities that arise from being able to shelter high-tax assets inside tax-favored retirement accounts. In particular, households are advised to hold all higher-tax-burden assets

1. For example, Dammon, Spatt, and Zhang [2004] estimate utility costs of tax-inefficient allocations to be up to $15 \%$ of total investable wealth for young households.

2. According to the Flow of Funds tables published by the Federal Reserve, self-directed retirement accounts totaled $\$ 4.4$ trillion at the end of 2002. These accounts include employer-sponsored defined contribution plans such as 401(k) and 403(b), similar plans for the self-employed such as Keogh and SEP-IRA, and individual retirement savings accounts such as Regular and Roth IRA. 
(bonds, in the case of the United States) inside TDAs. Only in cases when desired holdings of high-tax assets exceed TDA capacity, can some of them spill over into taxable accounts. These strictly specialized asset location choices have acquired the label of "tax-efficient". ${ }^{3}$ Taxefficient portfolios appear to be optimal even in complex environments of recent theoretical models [e.g. Huang 2001; Shoven and Sialm 2004; Dammon, Spatt, and Zhang 2004 (henceforth DSZ)].

The robustness of these conclusions with respect to optimal portfolio choices presents an empirical challenge because observed portfolios are not tax-efficient. Survey data commonly show that the majority of U.S. households simultaneously hold bonds in their taxable accounts and equities in their TDAs [see Poterba and Samwick 1997; Bergstresser and Poterba 2004]. These households could improve their after-tax returns by simply rearranging their location and allocation choices.

The goal of this paper is to provide an empirical evaluation of the behavior of these households in the context of an alternative model of dual-habitat portfolio choice that attempts to bridge the gap between theory and data [Amromin 2003]. ${ }^{4}$ In this model, households face uninsurable labor income risk, manifested through catastrophic and very infrequent unemployment spells. These shocks, coupled with limited accessibility of TDA assets, create precautionary savings motives for some households. The precautionary motives induce a tradeoff between the desire to maintain tax-efficient allocations and concern over the need to make costly withdrawals from retirement accounts in the event of bad income draws. As a result, a model with both labor income risk and accessibility restrictions can generate optimal portfolio allocations that are not tax-efficient.

Of most interest, however, are the model's predictions about the cross-sectional distribution of household portfolio choices. The first testable prediction of the model is that there should exist two distinct types of portfolio choices - "tax-efficient" allocations for households with weak precautionary savings motives (due to a high level of accumulated assets

3. For the remainder of this paper, "tax efficiency" of portfolio allocations is defined in the very narrow sense of Tepper-Black. An allocation is said to be tax-efficient if a strict pecking order is observed - the highest-taxed asset is always located in the tax-preferred habitat before any lower-taxed assets can be placed there. Relative to this benchmark, any allocation in which this pecking order is violated is labeled "tax inefficient".

4. Other recent papers have also attempted to address this discord in a variety of ways. For example, Shoven and Sialm [2004] extend the asset set of the household to tax-exempt municipal bonds. Huang [2001] uses lumpy expenditure needs that are unavoidable at certain points over the lifecycle. DSZ [2004] add uncertain labor income and lumpy consumption shocks. These models are discussed in detail in Amromin [2003]. 
or low labor income risk), and mixed ("precautionary") asset allocations by the rest of the households. Indeed, the data from the Survey of Consumer Finances point to the disproportionate number of the very wealthy among tax-efficient households. In the 1995 and 1998 waves of the survey $65 \%$ of the households in the top wealth decile, accounting for $53 \%$ of all financial wealth, were either fully tax-efficient or quite close to it.

The other key message of the model is that the degree of tax efficiency - how close a given portfolio is to the "bonds in TDA, equities in taxable accounts" dictum - is inversely related to the intensity of precautionary motives. In other words, households with stronger precautionary motives are expected to hold higher equity shares in TDAs and lower equity shares in taxable accounts. The prediction itself is quite intuitive. When access to TDA assets is very costly, TDAs are used primarily to accumulate retirement wealth. In contrast, liquid taxable accounts are much better suited for smoothing potential income shocks. Thus, households that face high labor income risk and have limited liquid financial resources, satisfy their strong precautionary motives by choosing a safer portfolio mix in the taxable investment account and by decreasing their TDA contributions. To address their retirement savings concerns, they increase the share of equities in their tax-deferred accounts. Tax efficiency gets trumped both by precautionary motives in taxable accounts and by retirement savings motives in TDAs. ${ }^{5}$

Earlier theoretical and numerical studies of the effects of precautionary motives on portfolio choice [e.g. Kimball 1993; Bertaut and Haliassos 1997] considered a single investment habitat. They found that the presence of precautionary motives leads to lower portfolio equity shares. Empirical support for this hypothesis has been mixed. ${ }^{6}$ However, as argued above, precautionary motives are likely to have opposing effects on portfolio choices in taxable and taxdeferred accounts. Hence, differentiating between account habitats in empirical tests provides a novel way to identify precautionary effects in portfolio composition.

5. However, if there are no restrictions on accessibility of TDA assets, the precautionary motives can be satisfied by assets in either habitat and tax efficiency of allocations need not be violated. This should be the case with the Canadian system, which openly treats tax-favored "registered retirement savings plans" (RRSP) as just another means to smooth consumption. I am grateful to Michael Smart for pointing out this example.

6. An especially popular formulation of this test has been to look for a negative relationship between the share of equities in household portfolio and the degree of riskiness in its labor income as shown numerically in Cocco, Gomes, and Maenhout [forthcoming] and Viceira [2001]. Vissing-Jørgensen [2002] and Heaton and Lucas [2000] find strong effects, but Guiso et. al. [1996] conclude that labor income risk has small effects on portfolio choice, while Hochguertel [1997] finds that the sign of these effects may even occasionally be positive in his sample of Dutch households. 
I use household-level data from the Survey of Consumer Finances (SCF) to test both predictions: who holds tax-efficient portfolios and whose portfolios are "more" tax-efficient. Empirical results support the key insights of the model. In particular, I find that households with more volatile labor income and those subject to early withdrawal penalties on TDA assets are less likely to choose tax-efficient portfolios. I further find that factors associated with stronger precautionary savings motives, such as having a higher fraction of one's wealth in a tax-deferred account or a riskier labor income process, indicate stronger precautionary portfolio choices, consisting of a safer taxable account allocation and a riskier TDA mix.

Several recent empirical studies provided systematic analyses of household portfolio allocations between and within taxable and tax-deferred accounts. Bergstresser and Poterba [2004] present extensive evidence of a high degree of heterogeneity in habitat-specific portfolio location and allocation choices in the SCF and discuss the effects that age, wealth, income, and marginal tax rates have on these choices. However, their study does not explicitly consider the effects of labor income risk or liquidity constraints. Barber and Odean [2004] estimate relative preferences for holding various assets (e.g. munis, stocks, mutual funds) in taxable or taxdeferred brokerage accounts. Even though these data are sufficient to analyze whether households are tax-efficient, they cannot be used to address the extent of tax-inefficiency. In contrast, the empirical investigation in the present paper is based on specific predictions of dualhabitat portfolio model with precautionary savings motives and is able to assess tax-efficiency of complete household financial holdings.

The rest of the paper is structured as follows. Section II briefly reviews the existing literature and outlines the properties of portfolio allocations in a dual-habitat precautionary model. Section III describes the data and sets up the empirical tests, while section IV contains results of econometric analysis. Section V summarizes the results and offers directions for future research.

\section{Related literature on dual-habitat portfolio choice}

There exists a recent body of theoretical literature addressing portfolio decisions of individual investors with both taxable and tax-deferred savings options. The dual-habitat portfolio problem is solved numerically [Shoven and Sialm 2004] or through a combination of

analytical arguments and numerical methods [DSZ 2004; Huang 2001]. As alluded to earlier, the 
general message that emerges from solutions to these models is that the primary goal of the asset location decision is to achieve Tepper-Black tax efficiency. ${ }^{7}$ In the United States, equities are tax-favored in several respects. They are taxed at lower rates than interest-paying assets, are subject to tax breaks when used for bequests, and afford a timing choice for realization of capital gains/losses and the corresponding tax liabilities or refunds. For all these reasons, it is believed to be better to locate bonds in retirement accounts which defer taxation, have no use for timing capital gains or losses and are ill-suited for bequest planning. In this context, tax efficiency means giving preference to bonds in retirement accounts whenever possible.

These theoretical findings translate into the following empirical prediction: there should never be any equity holdings in TDAs as long as there are bond holdings in taxable accounts. In the extreme case of unlimited borrowing in taxable accounts, the specialization of accounts is complete - the retirement account is always entirely dedicated to bonds. When borrowing in taxable accounts is limited, it is possible to observe equities in TDAs, provided the overall desired bond holdings do not exhaust TDA capacity. Conversely, if the overall desired bond holdings exceed the limits of the retirement account, the spillover goes in the other direction the "surplus" bonds are observed in taxable accounts. Both cases, however, rule out keeping equities in TDAs while simultaneously holding bonds in taxable accounts.

Actual available portfolio allocation data do not conform to these predictions. Figure I presents empirical portfolio allocations from the cross section of U.S. households in the 2001 Survey of Consumer Finances that had assets in both taxable and tax-deferred accounts. The horizontal axis represents the share of a tax-deferred account held in bonds, and the vertical axis - the share of taxable account held in equities. Taking "bonds" and "equities" to be a short-hand for "high-" and "low-tax" assets for the moment, each of the axes measures the extent to which "tax-appropriate" assets are held in each of the two accounts. Consequently, points farther away from the origin are more tax-efficient. The Tepper-Black results suggest that all households should locate along the outer, "tax-efficient", frontier - segments BC where stocks spill over into TDA, and CD where bonds spill over into the taxable account. The size of each point is proportional to the number of households making this particular portfolio allocation choice, making it easier to assess the prevalence of tax-efficient portfolio choices. As summarized in

7. As described in detail in Amromin [2003] pp. 558-62, each of these models is capable of producing "taxinefficient" portfolio allocations for at least some households at some point in their lifecycle. However, when such allocations are advocated, they often have empirically implausible properties. 
Table I, among households with positive investable financial wealth in both account types in the $2001 \mathrm{SCF}, 4.3 \%$ had all-stock portfolios, $8.2 \%$ had all-bond portfolios (both of which would technically be tax-efficient), and an additional $21.9 \%$ were located on the tax-efficient frontier. ${ }^{8}$ The rest of these households - nearly $2 / 3$ in all - do not adhere to Tepper-Black tax-efficiency. ${ }^{9}$ Moreover, the relative share of tax-inefficient households has been growing steadily over time, mirroring the rise in stock ownership through tax-deferred retirement plans.

These facts highlight the empirical difficulties of the tax-efficient theory and suggest the need for its augmentation. As shown in Figure I, tax-inefficient households choose a mix of bonds and stocks in each habitat (i.e., locate in the interior of the allocation box) or locate on the other two boundaries (BA and AD). One plausible mechanism for enticing households to keep bonds outside of their TDAs is to introduce further sources of risk into their environment (e.g. labor income risk) and to emphasize limited accessibility of TDA assets for pre-retirement consumption. Taken together, non-financial risk and relative TDA illiquidity require a tradeoff between tax efficiency and asset accessibility in deciding on portfolio allocations and asset location. On the one hand, not holding bonds inside retirement accounts results in suboptimal portfolio returns. On the other hand, locking away riskless assets in illiquid accounts may prove costly if a household is hit by a bad labor income shock coinciding with poor market returns. As a result, households may plausibly choose both to hold bonds outside as means for smoothing their consumption and bonds inside as tax-efficient investment vehicles.

A dual-habitat portfolio model set up in such fashion shares two central features of precautionary savings models - uninsurable risk and credit market imperfections. As shown by Kimball [1990] and Carroll [1997], prudent households in such environment choose to hold buffer stocks of assets, which is commonly referred to as precautionary savings behavior. ${ }^{10}$ The canonical precautionary savings models did not take a stand on asset composition of buffer

8. As noted in the footnote to Table I, investable financial wealth includes financial assets outside of checking accounts, as well as assets in self-directed individual retirement savings plans. The choice of which assets should be considered investable and which investment choices should be regarded as tax-efficient will be addressed in detail in the next section. Furthermore, in order to account for likely measurement error, the definition of tax-efficiency is relaxed to allow for a $10 \%$ interval around the tax-efficient frontier as indicated by dotted lines in Figure I.

9. These proportions pertain only to households with positive financial wealth in both account types. As seen in Table I, the share of such households in the United States has been growing rapidly from only $33 \%$ in 1995 to nearly $46 \%$ in 2001 , largely as a result of increasing popularity of tax-deferred retirement accounts.

10. Precautionary savings are commonly defined as the incremental savings that a liquidity-constrained household makes when it faces labor income risk, compared to the certain income scenario. 
stocks. However, later theoretical [Kimball 1993] and numerical single-habitat studies [e.g., Bertaut and Haliassos 1997] found that precautionary savings motives lead to less risky portfolio choices, i.e. buffer stocks held in the form of safe and liquid assets. In the context of the dualhabitat portfolio allocation problem, such safe and liquid assets could be manifested through taxinefficient holdings of bonds outside of retirement accounts. ${ }^{11}$

The companion paper [Amromin 2003] presents numerical solutions for a dual-habitat model with precautionary motives in which labor income risk is specialized to catastrophic lowfrequency unemployment spells. In the model, a household chooses the level of consumption, contributions to each account, as well as their portfolio composition. This model can generate "precautionary portfolio effects", defined as deviations of portfolio choices of liquidityconstrained households facing labor income risk from the benchmark of tax-efficiency obtained in the certain income scenario. These effects are predicted to vary in intensity with the strength of household precautionary motives and the current paper focuses on empirical verification of this prediction.

The first result of the "precautionary" dual-habitat model is that it can easily accommodate tax-efficient behavior for particular types of households. This is analogous to the results reported in the traditional precautionary savings literature, whereby even with uninsurable income risk there may be agents that are either not exposed to that risk or are wealthy enough not to be affected by credit constraints [Carroll 1997; Carroll, Dynan, and Krane 2003].

To see this in the context of the portfolio allocation problem, consider again the tradeoff between missing out on tax advantages of TDA bond holdings and not having enough wealth on hand to ride out a bad shock. With a sufficient level of overall wealth, one can satisfy precautionary savings needs with equities in the taxable account. With large taxable balances, the risk of not being able to smooth shocks is smaller, and so bonds are optimally stored inside TDA. With this reasoning, the composition of buffer stocks depends on the level of wealth: the household wants to "buffer" with safe and liquid assets unless liquidity of safe assets costs too

11. Simulation results indicate that under plausible specifications of stochastic income processes, buffer stocks need to be not only liquid, but also include safe assets like bonds. Still, stronger theoretical results are needed to establish conditions under which buffer stocks necessarily contain riskless assets. 
much relative to the risks posed by equity buffers. ${ }^{12}$ Similarly, households that are not affected by the modeled type of risk can afford to concentrate on making tax-efficient location choices.

The other key message of the model is that precautionary portfolio effects are stronger for households with more pressing precautionary needs. The intensity of precautionary motives can be captured in a number of different ways that aggregate into two broad classes: (a) level of exposure to non-diversifiable risk and (b) tightness of liquidity constraints. For example, households that have a higher share of their wealth confined to TDA are subject to a tighter liquidity constraint, since less of their overall wealth is readily accessible. For a given level of labor risk, households with less non-TDA wealth face a higher likelihood of having to make expensive TDA withdrawals. They attempt to lessen this likelihood by decreasing the optimal equity share in their taxable account and by cutting back on TDA contributions. Since these households want to be prudent without completely forgoing the higher return potential of equity investments, they compensate for higher taxable bond holdings with higher TDA equity shares. ${ }^{13}$

The finding that equity shares in the two account types move in opposite directions in response to precautionary savings motives allows one to construct an alternative empirical test of the effects of such motives on portfolio composition. As discussed in the introduction, earlier tests have focused on composition of the overall portfolio and have produced mixed results. The mixed nature of the results may not be surprising if, say, higher labor income risk is associated with lower equity shares in taxable accounts and higher equity shares in TDAs. In this case, separating taxable and TDA holdings and looking at joint determinants of asset composition in each account type represents a sharper test. Admittedly, predictions of a particular numerical model do not rise to the level of an analytical proof, but they are suggestive enough to merit empirical investigation.

There are two important empirical advantages of using precautionary dual-habitat portfolio model to produce testable restrictions. The first is that the substantial existing literature on precautionary savings motives provides a clear guide for mapping model design to the data. In particular, this literature allows uninsurable risk to be defined through a variety of risky

12. Another way to think about this is to treat forgoing tax-efficiency in retirement account as a tax on wealth. The wealthier are exposed to a higher tax, and so have a stronger incentive to be tax-efficient.

13. The model in Amromin [2003] can directly accommodate only a few avenues for increasing precautionary savings motives, such as the share of wealth in illiquid TDA accounts, degree of their illiquidity (early withdrawal penalty), and probability of unemployment shocks. The empirical analysis will extend to additional gauges of precautionary concerns, such as housing equity and volatility of labor income. 
processes - stochastic labor income, demographic shocks, etc. - all of which can be measured at the household level. It also identifies household characteristics that are related to precautionary savings behavior, such as measures of labor income uncertainty, wealth, and ability to access credit markets.

The second advantage is that the idea of having accessibility restrictions on TDA holdings bind at the time of adverse labor income shocks conforms well to the existing tax law. Indeed, liquidity needs that arise from predictable lifecycle events such as house purchase and college expenses are partially exempt from strict withdrawal restrictions on retirement accounts. ${ }^{14}$ Using TDA assets to smooth labor income shocks is an entirely different story. If a TDA participant is still employed, they can tap TDA assets only by applying for a hardship withdrawal. Such withdrawals are allowed only in a limited number of circumstances and even if approved trigger early withdrawal penalties. If a TDA participant loses her job, any TDA assets not rolled over into a new TDA within 60 days are subject to a $10 \%$ penalty. This penalty effectively applies even in the case of borrowing against TDA, which is a common feature of many retirement plans. Under the current law, a participant that loses her job while carrying a loan balance has to repay the entire loan immediately in order to avoid penalties. Hence, in a job loss scenario, both ways of accessing TDA assets for current consumption are costly.

\section{Empirical Framework}

The discussion in the previous section suggested that (1) existence of precautionary savings motives coupled with TDA accessibility constraints may lead some households to forgo tax-efficient portfolio allocations and (2) stronger precautionary motives may result in greater deviations from Tepper-Black efficient portfolio choices. This section maps these two predictions into specific empirical tests.

\section{III.A. Extensive margin of tax-efficiency - which households are tax-efficient?}

14. Both exemptions became law in 1997, as a part of Taxpayer Relief Act. The education withdrawals can apply towards tuition, as well as room and board and they can be taken out for oneself, one's children or even grandchildren. There isn't a fixed dollar limit on such withdrawals and as long as all of it goes toward qualified education expenses, no penalties are due. The housing exemption applies to "first-time" homebuyers and is capped at $\$ 10,000$ for each of the partners (up to $\$ 20,000$ ). "First-time" is defined only as "not having owned a primary residence for the past 2 years". Both of these apply only to assets taken out of non-employer-sponsored TDAs, such as IRAs and rollover IRAs. 
As argued earlier, households not subject to precautionary motives or liquidity restrictions on their TDA holdings have little incentive to sacrifice tax-efficiency of their portfolio choices. Consequently, the likelihood of holding tax-efficient portfolios is expected to be higher for households that:

(a) have more financial or housing wealth, so they are less liquidity constrained;

(b) have penalty-free access to their retirement wealth, i.e. are over the age of 591/2.;

(c) have a lower share of their wealth held in TDAs, which restrict accessibility;

(d) have less risky labor income processes;

(e) have health insurance coverage for all household members;

The costs of tapping into TDA assets prior to retirement are given not only by withdrawal penalties, but also by forgone opportunities for tax-deferred wealth accumulation. ${ }^{15}$ Such costs are higher for young households and households in high marginal tax brackets. Therefore, if holding bonds in TDA makes TDA withdrawals more likely, the likelihood of tax-efficient portfolios should increase monotonically with age and marginal tax rate. This is different from predictions of models with demographic liquidity needs such as education and house purchase, where only households of certain ages hold bonds in taxable accounts.

In tests of the extensive margin decision below all households are broken into two distinct sets - tax-efficient households whose portfolios do not simultaneously contain bonds in taxable accounts and equities in TDAs, and everyone else. This means that households that completely specialize in a single asset class (i.e. whose portfolios are all-stock or all-bonds) are classified as tax-efficient by default.

\section{III.B. Intensive margin of tax-efficiency - how tax-efficient are households?}

One can think of stronger precautionary savings motives as deriving from two sources: (1) higher background risk and (2) tighter liquidity constraints. These pressures can be captured by variables listed in (a)-(e) above. It is intuitive that higher income uncertainty and lesser ability to smooth consumption would be generally associated with lower equity holdings in liquid taxable accounts. The implications for composition of tax-deferred accounts are less straightforward. On the one hand, high labor income risk may decrease the fraction of TDA in equities by depressing total stock holdings. On the other, TDA equity exposure can increase in

15. In their analytical section, DSZ [2004] show that under certain conditions these costs may be sufficient to make it optimal to hold bonds in taxable accounts even in the absence of withdrawal penalties. 
response to rebalancing towards safer buffer holdings outside TDAs. Which effect dominates depends heavily on the overall location/allocation decision of the household.

The numerical results in Amromin [2003] indicate that the two key components of the model - the distribution of wealth between accounts and the presence of accessibility restrictions - will produce the precautionary portfolio effects summarized in the table below.

\begin{tabular}{|c|c|c|}
\hline \multirow[b]{2}{*}{ Explanatory variables } & \multicolumn{2}{|c|}{ Expected effect on } \\
\hline & TDA $\%$ in equities & Taxable acct. $\%$ in equities \\
\hline \multicolumn{3}{|l|}{ Tighter liquidity constraints } \\
\hline $\begin{array}{l}\text { (share of wealth in TDA, TDA accessibility } \\
\text { restrictions, housing equity) }\end{array}$ & + & - \\
\hline \multicolumn{3}{|l|}{ Higher background risk } \\
\hline $\begin{array}{l}\text { (probability of unemployment, volatility of } \\
\text { labor income, health care coverage) }\end{array}$ & + & - \\
\hline
\end{tabular}

That is, households with stronger precautionary motives would choose portfolios that are farther away from the tax-efficient frontier (i.e. have more stocks in TDA and fewer stocks in taxable accounts). In terms of Figure I, tighter liquidity constraints and/or higher background risk will push portfolio allocations closer to the origin. As indicated in the table, empirical tests will be extended to proxies of risk and liquidity beyond those evaluated in the numerical model. It is worth noting that in addition to measuring liquidity constraints, the share of TDA holdings in overall wealth also proxies for the location choice. Given the simultaneity of contribution and allocation decisions, it is particularly important to account for the location choice in evaluating portfolio composition.

These empirical predictions are quite different from those derived from models that allow only tax-efficient outcomes. For instance, such models would predict a positive relationship between share of wealth in TDA and equity shares in both accounts, due to the asset spillovers discussed earlier. They also have no explicit role for either accessibility restrictions or background risk in determining tax-efficiency of portfolio choice.

\section{III.C. Data description}

The data used in this study come from the three latest Surveys of Consumer Finances, conducted in 1995, 1998, and 2001. The surveys are conducted by the Board of Governors of 
the Federal Reserve System and cover a substantial cross-section of U.S. households in each survey year. There are 4299, 4305, and 4442 households, respectively, in the surveys studied here. The surveys ask a wide array of questions on every aspect of household financial situation - amount and type of liquid and illiquid assets, nature and value of proprietary business holdings, availability and price of credit, sources of earnings, etc. Of particular value for studies of household portfolio composition is the fact that the SCF oversamples wealthy households, which tend to have richer portfolio structures. Each survey makes available a set of sampling factors that allow one to re-weight the sample to produce population statistics. Unless otherwise noted, all descriptive statistics utilize population weights.

The SCFs attempt to uncover precise composition of household financial portfolios. Unfortunately, information on allocations to narrowly defined asset classes exists only for funds kept in taxable investment accounts. By contrast, the composition of holdings in tax-deferred retirement accounts, both individual (like IRA and Keoghs) and employer-sponsored (i.e. 401k, $403 \mathrm{~b}$ ) has to be inferred from categorical responses. For example, the question on allocation of IRA holdings asks, "How is the money in this account invested? Is most of it in...?" Following this question there is a table of possible answers, with separate categories for cash, stocks, and bond holdings (both direct and through mutual funds), and several additional categories that allow joint holdings of combinations of these assets. Clearly, some assumptions are needed to translate these qualitative measures into dollar figures. I use a mapping that assigns all of the account value to a category that is indicated to be the single category in which "most" holdings are invested. If a combination of categories is chosen, the account value is allocated in equal proportions. The resulting raw allocations of assets in retirement portfolios closely match those in earlier studies [e.g. Ameriks and Zeldes 2000].

The necessity to impute equity shares in retirement accounts in this fashion explains the agglomeration of observations at certain points on the x-axis in Figure I. For example, a vertical line at 50\% TDA allocation corresponds to holdings of households with only one of the two types of retirement accounts (IRA/Keogh or $401 \mathrm{k} / 403 \mathrm{~b}$ ) who reported that their tax-deferred assets were split between equities and bonds.

In order to conduct empirical tests, key components of theoretical models need to be given operational meaning. I define investable household wealth as total quasi-liquid financial assets that can be explicitly allocated between investments with equity- or bond-like properties. 
The taxable account component of such wealth includes nearly all financial instruments such as mutual fund investments, savings accounts, and CDs. It specifically excludes checking accounts on the grounds that they are used primarily for transaction purposes, as well as housing and proprietary business wealth, and human capital wealth. ${ }^{16}$ The tax-deferred component of investable wealth consists of retirement accounts that allow participants to choose asset allocation. This category includes most of the defined contribution plans such as $401 \mathrm{k}$ and TIAA-CREF, as well as individual retirement accounts such as IRA and Keogh, but it omits imputed values of future guaranteed pension income (Social Security, defined benefit plans).

A particularly important task is to define "stocks" and "bonds". Typically, "bonds" have been interpreted directly as corporate, municipal, and government bonds traded on financial markets. The ownership of such assets is extremely skewed in the population, and they do not nearly exhaust the set of financial instruments that provide safe return and are highly liquid. Since I intend to focus on the precautionary behavior of households, I augment this set of assets with money market and savings accounts, which face the same tax treatment as conventional bonds. However, to define "tax-efficiency" properly one needs to account for differences in tax treatment among "bond-like" assets. In particular, since municipal bonds and U.S. savings bonds receive preferential tax treatment, I count them as low-tax "equities" which should be located in taxable accounts. ${ }^{17}$ Consequently, the share of "equities" held in taxable accounts is defined as the sum of directly held stocks, stock mutual funds, munis, and U.S. savings bonds divided by total investable taxable wealth. This definition will also allow me to highlight the puzzle identified in Shoven and Sialm [2004] and Poterba, Shoven, and Sialm [2000] - holding munis in taxable accounts allows households to satisfy their precautionary motives and be taxefficient at the same time. Yet, as shown in Figure I and as will be analyzed below, households do not follow this practice.

16. Some recent studies [e.g. Flavin and Yamashita 2002] focus on the role of housing wealth, which represents the single largest component of wealth for many U.S. households. Housing wealth serves as an important mechanism for relaxing liquidity constraints through home equity loans and lines of credit. Hence, I control for housing wealth in empirical work, but it does not enter the definition for portfolio composition of investable wealth. Heaton and Lucas [2000] demonstrated that proprietary business holdings are an important component of household portfolios. Such holdings are typically less liquid and more volatile than purely financial assets. Although the current version of the paper excludes these holdings, it would be useful to conduct robustness checks on the definition of wealth in the future.

17. I am grateful to Jim Poterba for drawing my attention to this important detail. 
To obtain a measure of conditional moments of labor income processes, I compute estimates of standard deviations of labor income shocks from the 1985-1993 data in the Panel Study of Income Dynamics. The choices of the functional form for the labor income process and the econometric method for estimating its components are similar to Carroll and Samwick [1998] and Vissing-Jørgensen [2002]. The details of specification and estimation, as well as data selection criteria are specified in the Appendix. After conditional moments of labor income are computed for each household in the sample, they are averaged within each occupation-education group. I also obtain cross-sectional probabilities of unemployment for each occupationeducation group from the Job Tenure Supplement of the Current Population Survey. These group means are then used as point estimates of labor income uncertainty for corresponding demographic cells in the SCF. The fact that regressors measuring labor income uncertainty are themselves imputed introduces an additional source of sampling error in model estimation. The estimation method, which is based on Hansen's [1982] application of GMM to multi-step estimators and Newey's [1987] AGLS estimator for limited dependent variable models, takes this error into account.

\section{Empirical Results}

\section{IV.A. Econometric model}

To analyze tax-efficiency of portfolio choices while allowing for the simultaneity of the overall location decision I need to use econometric models of limited dependent variables with endogenous regressors. In the case of the extensive margin choice (whether to be tax-efficient), the dependent variable is binary. In the case of the intensive margin choice (the degree of taxefficiency), the dependent variables are given by the portfolio composition in each of the two account types and hence they are limited to be between 0 and 1 . In both cases, one of the key explanatory variables - the share of wealth held in TDA (swlthTDA) - is an endogenously determined proxy of location choice (and of liquidity constraints). The resulting econometric model has a common structure given by:

$$
y_{\mathrm{i}}{ }^{*}=\beta_{1}+\beta_{2} M_{\mathrm{i}}+\beta_{3} W_{\mathrm{i}}+\beta_{4} L_{\mathrm{i}}+\beta_{5} H_{\mathrm{i}}+\beta_{6} D_{\mathrm{i}}+u_{\mathrm{i}}, \mathrm{i}=1, \ldots, \mathrm{N},
$$

where for the extensive margin choice the observed dependent variable is defined as:

$$
y_{\mathrm{i}}=1 \text { if } y_{\mathrm{i}}^{*}>0,0 \text { otherwise, }
$$

and for the intensive margin choice the observed dependent variables specialize to: 


$$
y_{\mathrm{i}, \mathrm{k}}=0 \text { if } y_{\mathrm{i}, \mathrm{k}} * \leq 0 ; y_{\mathrm{i}, \mathrm{k}}=y_{\mathrm{i}, \mathrm{k}} * \text { if } y_{\mathrm{i}, \mathrm{k}} * \in(0,1] ; k \in\{\mathrm{TDA}, \text { taxable }\} .
$$

The endogenous variable swlthTDA is assumed to be related to a vector of instruments $\left[X_{1} X_{2}\right]$, where $X_{1}$ denotes variables that are included in (1) and $X_{2}$ represents excluded instrumental variables:

$$
\text { swlthTDA } A_{\mathrm{i}}=\Pi_{1} X_{\mathrm{i} 1}+\Pi_{2} X_{\mathrm{i} 2}+\varepsilon_{\mathrm{i}},(u, \varepsilon) \sim \operatorname{MVN}(\mu, \Sigma) .
$$

The set of explanatory variables is based on the discussion in the previous section and is broken into several subsets for convenience. $M$ is a subset of variables that proxy for illiquidity of household wealth due to its TDA holdings - share of wealth in TDA and an indicator of being subject to the early withdrawal penalty. $W$ consists of financial and housing wealth. $L$ contains estimates of the conditional volatility of labor income by occupation and education, derived from PSID data. The regressors in $L$ also include the probability of unemployment estimated for the same demographic groups using CPS data and a dummy variable for households with two income earners. As long as these income streams are not perfectly positively correlated, dualearner households have (ceteris paribus) less volatile labor income. $H$ contains additional indicators of the extent to which a household may be subject to precautionary motives. These binary variables capture whether the main self-reported motive for savings was precautionary, whether all members of household are covered by health insurance, and whether the household has enough liquid assets to satisfy self-reported liquidity needs. ${ }^{18}$ Finally, $D$ represents a subset of demographic variables - education category dummies and a quadratic in age.

An additional complication of the model in (1)-(2) is that the regressors in $L$ are themselves generated on the basis of household labor income characteristics obtained from additional data sources - the Current Population Survey and the Panel Study of Income Dynamics. These generated regressors make it a bit more difficult to apply Newey's [1987] estimator for limited dependent variable models with endogenous explanatory variables. ${ }^{19}$ To account for sampling error in the generated regressors, I restate the AGLS estimator in the GMM

18. Self-reported liquidity needs were determined from responses to the following question: "About how much do you think you (and your family) need to have in savings for emergencies and other unexpected things that may come up?" A household that has enough liquid assets (whether high- or low-tax ones) to satisfy these needs would be more likely to have a tax-efficient portfolio.

19. Newey's [1987] estimator has a form of Amemiya's [1978] generalized least squares (AGLS), where parameters of the limited dependent variable equation (such as (1) above) are estimated by maximum likelihood after substituting for the endogenous variable with a reduced form equation (such as (2) above). The structural parameters of (1) are then backed out via a generalized least squares approach. 
framework for multi-step estimators [Hansen 1982]. This modification is illustrated for the case of the bivariate tobit model of portfolio choice (the intensive margin choice). Using (1), and making explicit the bivariate nature of the dependent variable in $(1 \mathrm{~b})$, the model is given by:

$$
\begin{aligned}
& \left\{\begin{array}{l}
y_{\mathrm{i}, \text { taxable }}{ }^{*}=\beta_{1}+\beta_{2} M_{\mathrm{i}}+\beta_{3} W_{\mathrm{i}}+\beta_{4} \tilde{L_{\mathrm{i}}}+\beta_{5} H_{\mathrm{i}}+\beta_{6} D_{\mathrm{i}}+u_{\mathrm{i}}, \mathrm{i}=1, \ldots, \mathrm{N} ; \\
y_{\mathrm{i}, \mathrm{TDA}}{ }^{*}=\gamma_{1}+\gamma_{2} M_{\mathrm{i}}+\gamma_{3} W_{\mathrm{i}}+\gamma_{4} \tilde{L_{\mathrm{i}}}+\gamma_{5} H_{\mathrm{i}}+\gamma_{6} D_{\mathrm{i}}+v_{\mathrm{i}}, \mathrm{i}=1, \ldots, \mathrm{N} ; \\
y_{\mathrm{k}}=0 \text { if } y_{\mathrm{k}}{ }^{*} \leq 0 ; y_{\mathrm{k}}=y_{\mathrm{k}}{ }^{*} \text { if } y_{\mathrm{k}}{ }^{*} \in(0,1], k \in\{\mathrm{TDA}, \text { taxable }\}
\end{array}\right. \\
& \text { swlthTDA } A_{\mathrm{i}}=\Pi_{1} X_{\mathrm{i} 1}+\Pi_{2} X_{\mathrm{i} 2}+\varepsilon_{\mathrm{i}} \cdot(u, v, \varepsilon) \sim \operatorname{MVN}(\mu, \Sigma) \text {. }
\end{aligned}
$$

The regressors in $\tilde{L}$ are imputed on the basis of auxiliary parameter estimates $\left(\theta^{\mathrm{CPS}}, \theta^{\mathrm{PSID}}\right)$, which are obtained by running OLS regressions of each of the components of $L$ on a collection of education and occupation dummies in PSID and CPS:

$$
\begin{aligned}
& \tilde{L_{\mathrm{i}}}=\left[\operatorname{prob}\left(\mathrm{U}_{\mathrm{i}}\right), \sigma_{\mathrm{i}}\right]=\left[Z_{\mathrm{i}} \theta^{\mathrm{CPS}}, Z_{\mathrm{i}} \theta^{\mathrm{PSID}}\right] ; \\
& L_{\mathrm{i}, \mathrm{k}}^{\mathrm{s}}=\theta^{\mathrm{s}} Z_{\mathrm{i}}^{\mathrm{s}}+v_{\mathrm{i}}^{\mathrm{s}}, \mathrm{k} \in\{\mathrm{TDA}, \text { taxable }\} \text { and } s \in\{\text { PSID }, \mathrm{CPS}\}, \mathrm{i}=1, \ldots, \mathrm{N}^{\mathrm{s}} .
\end{aligned}
$$

where $Z^{\mathrm{S}}{ }_{\mathrm{i}}$ is an $(m \times 1)$ vector of dummy variables in sample $s$, and where 1 in the $m$-th row means that household $i$ belongs to an occupation-education cell $m$.

Estimation is based on the following set of moments:

$$
\left\{\begin{array}{l}
\mathrm{g}\left(\mathrm{w}_{\mathrm{i}},[\alpha \eta], \Pi\right)=\partial \mathscr{L}_{1}\left(w_{\mathrm{i}} ;[\alpha \eta], \Pi\right) / \partial\left(\left[\alpha^{\prime} \eta^{\prime}\right]^{\prime}\right) \\
\mathrm{m}\left(\mathrm{w}_{\mathrm{i}}, \Pi\right)=X_{\mathrm{i}}^{\prime}\left(Y_{\mathrm{i}}-X_{\mathrm{i}} \Pi\right) \\
\mathrm{p}\left(\mathrm{p}_{\mathrm{i}}, \theta^{\mathrm{PSID}}\right)=Z_{\mathrm{i}}^{\mathrm{PSID}}\left(X_{\mathrm{i}}^{\mathrm{PSID}}-Z_{\mathrm{i}}^{\mathrm{PSID}} \theta^{\mathrm{PSID}}\right) \\
\mathrm{c}\left(\mathrm{c}_{\mathrm{i}}, \theta^{\mathrm{CPS}}\right)=Z_{\mathrm{i}}^{\mathrm{CPS} \prime}\left(X_{\mathrm{i}}^{\mathrm{CPS}}-Z_{\mathrm{i}}^{\mathrm{CPS}} \theta^{\mathrm{CPS}}\right)
\end{array}\right.
$$

Here $w_{\mathrm{i}}=\left[y_{\mathrm{i}}, M_{\mathrm{i}}, W_{\mathrm{i}}, \tilde{L_{\mathrm{i}}}, H_{\mathrm{i}}, D_{\mathrm{i}}, X_{\mathrm{i}}\right], \alpha=[\beta, \gamma], \eta$ represents nuisance parameters $\left(\sigma_{1}, \sigma_{2}, \rho\right)$ and $\mathscr{L}_{1}$ is the conditional log-likelihood function for bivariate tobit [Greene 1995]. ${ }^{20}$ The details of estimation are available on request, but two points can be made here. The first is that most of the moment conditions in (6) can be assumed to be mutually independent, since they are computed using data from three different surveys. Since it is unlikely that same people were chosen for participation in these surveys, the assumption of independence is not unreasonable. As a result, the complexity of the estimator is greatly reduced. The second point is that all necessary information from other samples needed to correct the variance-covariance matrix of structural coefficients $\beta$ and $\gamma$ for the fact that regressors in $L$ are generated, is contained in consistent

20. The estimator for the extensive margin choice is essentially the same with the first moment condition in (6) replaced with $\mathrm{g}\left(\mathrm{w}_{\mathrm{i}}, \beta, \Pi\right)=\partial \mathscr{L}_{2}\left(w_{\mathrm{i}} ; \beta, \Pi\right) / \partial\left(\beta^{\prime}\right)$, where $\mathscr{L}_{2}$ is the conditional log-likelihood function for probit. 
estimators of $\operatorname{Var}\left(\theta^{j}\right)$. The "size" of these estimated $\operatorname{Var}\left(\theta^{j}\right)$ matrices is one of the key determinants of the magnitude of corrections for generated regressors. Both of the samples PSID and CPS - are rather large. ${ }^{21}$ Given the size of these samples and the nature of computed parameter vectors (simple demographic cell means), it is not surprising that both $\theta$-vectors are very precisely estimated. Consequently, the correction to standard errors that is due to the presence of generated regressors is very small. While accounting for the presence of such regressors remains a very important theoretical concern, its practical implications are quite limited in the current application.

\section{IV.B. The location choice - determinants of share of wealth held in TDA}

With this in mind, we can concentrate on estimating the two margins of tax-efficiency of household portfolio choice, which are based on equations (1-2). These equations represent a familiar two-stage estimator setup and even though the estimator used in the paper is somewhat different, it is helpful to think of the model in that way. Both decisions share a common endogenous variable - share of wealth in TDA ( $\operatorname{swlthTDA)}$ - which is described by equation (2). In equation (2), $X_{1}$ denotes instrumental variables that are included in (1), while $X_{2}$ represents excluded instrumental variables. The extent to which the endogeneity problem can be resolved depends critically on the choice of the excluded instrument $\mathrm{X}_{2}$. Ideally, $\mathrm{X}_{2}$ would be related to the portfolio shares in each account only through $s w l t h T D A$ and its relationship with $s w l t h T D A$ would both be plausible and verifiable.

I consider several alternative choices of the instrumental variable: size of the firm where the head of the household works, household eligibility for high-limit employer-sponsored retirement plan, and the size of employer match. Each of these variables serves as an important predictor of whether a household has access to employer-sponsored retirement plans, which have much higher contribution limits than IRAs. Hence, each of these instruments should be strongly positively related to the share of wealth that could be assigned to tax-deferred accounts.

The issue of whether these instruments only contribute to portfolio choice through their effects on the relative size of retirement holdings is more contentious. An argument can be made that matching of households with jobs is not random across firm sizes, but rather reflects underlying risk preferences. One way to assess this concern is to look at a self-reported measure

21. The PSID panel used for estimation of $\theta^{\text {PSID }}$ consists of 1,396 households, with 9 observations per household. The CPS sample used for estimation of $\theta^{\mathrm{CPS}}$ has 120,477 observations. 
of willingness to take financial risks, available in the SCF. Table II displays the means of various risk-taking categories by firm size. There is no strong evidence that conditional means of household attitudes toward financial risk vary across firm size. This is particularly true of the extreme categories - "willing to take very high investment risk" and "unwilling to take any risk".

Another concern with using firm size as an instrument is that larger firms are more likely to provide matching TDA contributions in the form of company stock. Indeed, a recent survey conducted by Profit Sharing/401k Council of America indicates that while 37\% of corporations with more than 5,000 employees match with company stock, only $3 \%$ of companies with less than 500 employees do the same. ${ }^{22}$ Benartzi [2001] and Liang and Weisbenner [2002] show that employees in firms with matching stock contributions tend to hold a greater share of their taxdeferred accounts in company stock even when such contributions are freely tradable. Thus, firm size may be indicative of a larger equity share in retirement accounts through its association with company stock matching contributions. Unfortunately, the SCF does not provide any data to gauge the potential severity of this problem.

In contrast, the other two instrumental variables do not carry information about exogenous features of employer-sponsored retirement plans, and so are less likely to influence portfolio choice directly. ${ }^{23}$ An accurate measure of household eligibility can be constructed from a number of sequential responses to questions about features of employment-related pension coverage in the SCF. I follow the methodology in Pence [2002a] to identify households that are eligible for (but do not necessarily participate in) high-limit defined contribution retirement plans. An important addition is the extension of the definition of eligibility to self-employed households. Under the current tax code, unincorporated businesses have the right to open IRAtype accounts that have very high contribution limits and nearly unrestricted choice of investments. $^{24}$

22. This difference is also due to the fact that smaller firms rarely have publicly traded stocks. As a result, they are much less likely to offer equity interest in the company as an investment option (13.5\% as compared with $76.7 \%)$.

23. Even though eligibility is a direct measure of the extent of TDA saving opportunities (as opposed to firm size), it is not an ideal instrument because of its relationship with the underlying household preferences [see Weisbenner 1999, Pence 2002a, 2002b] for a detailed discussion of selection and education effects). Similar concerns can also be raised with respect to the size of employer match.

24. There are several such accounts - Keogh, SEP-IRA, etc. - all of which have high contribution limits. For example, Keogh plans allow one to save up to $\$ 40,000$ per year in combined employee and employer contributions. 
Given potential drawbacks of these instruments, I estimate two versions of the reducedform equation for the endogenous regressor (equation 2). Table III presents the results of OLS estimation of the determinants of the location choice. The model is estimated on a subset of households that have both account types, in order to avoid including trivial 0-portfolio choices. As hypothesized, the share of wealth in TDA has a strong positive relationship with each of the three instruments that proxy for availability and attractiveness of employer-sponsored retirement accounts. Also, as expected, strict limits on contributions to retirement accounts result in a strong inverse relationship between the level of wealth and its share in TDAs. ${ }^{25}$ Households that save primarily for precautionary reasons keep less of their wealth in TDAs, as do those that are no longer subject to early TDA withdrawal penalties (although the latter relationship has only marginal statistical significance). As indicated by the comparison of the two panels of Table III, these results are quite robust to the choice of instrument.

Notably, the share of wealth in TDAs is also found to depend negatively on the level of riskiness of the household's labor income. As conditional standard deviation of labor income declines from its $75^{\text {th }}$ percentile value to $25^{\text {th }}$ percentile, the share of wealth held inside TDA increases from 3.1 to 4.5 percentage points (using coefficient estimates in panels A and B, respectively). Similarly, households that can rely on dual labor income streams hold a higher share of their wealth in TDA. This finding is important because it shows that the location decision of a household is an active choice variable influenced by the level of uncertainty in labor income, and not just a deterministic function of household wealth. That is, of the two households with identical wealth levels, the one with greater income uncertainty will have contributed less of its wealth to the tax-deferred retirement account.

\section{IV.C. Which households are more likely to be tax-efficient?}

The estimated structural coefficients of the probit model of tax-efficiency of household portfolio choice are presented in Table IV ${ }^{26}$ Consistent with definitions in Table I and Figure I,

25. In order to correct for extreme skewness in distribution of financial and housing wealth, I use the inverse hyperbolic sine function advocated by Carroll, Dynan, and Krane [2003]. This transformation is described by $\gamma(\mathrm{W}, \theta)=\ln \left(\theta \mathrm{W}+\left(\theta^{2} \mathrm{~W}^{2}+1\right)^{0.5}\right) / \theta$, where $\theta$ controls the degree to which large values are downweighted. Unlike log transform, $\gamma$-transform can handle negative and zero observations as well.

26. In an unreported exercise, I test for sample selection bias produced by restricting the regression sample to households that have positive wealth in both account types. The likelihood ratio test of independence of the selection and tax-efficiency equations in the Heckman sample selection probit model cannot be rejected at the 10 percent confidence level. 
the dependent variable takes on a value of 1 if household portfolio lies in the $10 \%$ band around the tax-efficient frontier. The results are broadly consistent with the hypotheses put forth in section III.A. In particular, households with higher values of $s w l t h T D A$ are significantly less likely to maintain tax-efficient portfolios. Departing from its mean sample value of 40 percent, each percentage point increase in the share of wealth held in TDA is associated with a 1.2 percentage point reduction in the likelihood of holding a tax-efficient portfolio. All else equal, households with a greater share of wealth in retirement accounts are more liquidity constrained, which increases the odds of tapping TDA funds early to smooth income shocks. One way to avoid this is by holding tax-inefficient portfolios, as implied by the negative coefficient estimate. Also consistent with this logic is the finding that being subject to early withdrawal penalties decreases the likelihood of tax-efficiency by about 7 percentage points.

The hypotheses regarding the effects of wealth and labor income risk receive somewhat mixed support in the data. Although households with more financial wealth are more likely to be tax-efficient, I fail to detect an independent effect of housing wealth. Similarly, standard deviation of labor income is estimated to have a statistically significant negative effect on household tax-efficiency. However, other measures of labor income risk do not generate statistically identifiable effects, and neither does health insurance coverage. Still, none of the coefficient estimates is inconsistent with the hypothesis of an inverse relationship between the precautionary savings motives and likelihood of portfolio tax-efficiency.

Households that have sufficient taxable assets to satisfy their self-reported precautionary needs are found less likely to hold tax-efficient portfolios. Controlling for total financial wealth, such households are characterized by high equity holdings in both account types. Consequently, the only way for such households to avoid being labeled "tax-inefficient" is through holding very few (less than 10\%) of their taxable accounts in bond-like assets, which few of them do. The puzzling finding of the likelihood of tax-efficiency declining monotonically with age (until the age of 60) has its explanation in a similar source. The age profile of stock market participation rises quickly through the peak earnings years [e.g. Ameriks and Zeldes 2000; Banks, Blundell, and Smith, 2002]. In recent years, initial equity ownership occurred primarily through employersponsored TDAs [Gale and Pence 2004]. These TDA equity holdings coupled with taxable money market accounts accumulated by households early on in their lifecycle, lead to an association between tax-inefficiency and increases in equity participation with age. This 
mechanism is also the likely source for a strong negative time trend in tax-efficiency, as much of the increase in the number of positive financial wealth households between 1995 and 2001 could be attributed to TDA participation (see Table I).

\section{IV.D. What determines the degree of tax-inefficiency in household portfolios?}

The above analysis of the stark binary choice of whether to hold tax-efficient portfolios highlights the key reasons for empirical shortfalls of the Tepper-Black type models. However, the question of greater practical interest is the extent of household tax-inefficiency. The investigation of this question can take two distinct forms. Bergstresser and Poterba [2004] provide a comprehensive analysis of the absolute magnitudes of misallocated assets, which are directly related to estimates of financial losses resulting from tax-inefficiency. Taking a somewhat different focus, I look to identify specific causes for relative deviations of household portfolios from tax-efficient benchmarks by analyzing portfolio composition in each of the two account types. This approach also provides a novel test of the effects of precautionary motives on portfolio choices.

Portfolio allocations in both accounts are modeled jointly, in order to account for simultaneity of such choices. This is accomplished by choosing a bivariate tobit model with correlated error structure, where error terms in each equation include unobserved (or omitted) household-specific factors. The resulting econometric model is described by equations (3a-3b) and (2).

\section{$\underline{\text { Portfolio choice in taxable account }}$}

The estimation results of the bivariate tobit model of portfolio choice are presented in Table V. The left panel shows Newey's asymptotically efficient estimates of structural coefficients for portfolio choice in the taxable account. The estimated coefficients are of correct sign and most are statistically significant. As hypothesized in section III.B., households with higher values of $s w l t h T D A$ have lower equity shares in their taxable portfolios. This effect has strong economic significance - moving a household from the $25^{\text {th }}$ percentile of swlthTDA $(0.12)$ to the $75^{\text {th }}$ percentile $(0.66)$ while holding wealth levels unchanged would decrease the equity share in taxable account by 18.5 percentage points. Being subject to withdrawal penalties is found to have a negative, though not statistically significant effect on the taxable account equity shares. In contrast, measures of labor income uncertainty have strong negative effects on the share of taxable portfolio dedicated to equities. The smaller magnitude of marginal effects of 
these regressors (for example, increasing standard deviation of wages from the $25^{\text {th }}$ to the $75^{\text {th }}$ percentile value leads to a decline in equity share of 2.4 percentage points) is not surprising in light of the first stage results. Holding more housing wealth (and hence having better access to credit markets) is associated with higher taxable equity shares, but having health insurance coverage (and thus being exposed to less background risk) is not. Another interesting finding is that households saving primarily for precautionary motives have somewhat less equity exposure in their taxable portfolios, even after controlling for numerous proxy measures of such motives. While the results in Panel A are suggestive of the importance of the strength of precautionary motives, one needs to consider them jointly with those for the TDA portfolio choice in order to test model predictions.

\section{$\underline{\text { Portfolio choice in TDA }}$}

The structural parameters for TDA portfolio allocations are shown in panel B of Table V. The estimates provide qualified support for the precautionary savings channel of moving households away from Tepper-Black tax-efficiency.

The share of wealth held in TDA is estimated to have a strong positive effect on TDA equity share. This result is particularly important given the finding of an opposite relationship between equity share and location in the taxable account. Such differential relationship between location and allocation choices in the two account types is a distinguishing feature of the precautionary portfolio model that is able to generate tax-inefficient behavior. ${ }^{27}$ Another key result is that being subject to early withdrawal penalties increases TDA equity shares ( $p$-value of 0.066). Even though the coefficient estimate of this regressor in panel A was not statistically significant, the opposite signs of the effects of TDA penalties on equity shares in the two account types are consistent with the precautionary model. Similarly, positive effects of conditional standard deviation of wages on TDA equity share are in contrast to their negative relationship with the share of taxable account held in equities (again, the estimate is at best marginally significant, with a p-value of 0.09). However, the effects of other measures of household labor income risk and of housing wealth are not estimated precisely enough to be statistically significant. In general, the precision of coefficient estimates of the TDA portfolio choice is markedly lower than that in the taxable portfolio choice. This can be at least partially attributed

27. Recall that in models that generate Tepper-Black tax-efficient outcomes, swlthTDA has a positive relationship with equity shares in both accounts types. 
to the necessity to impute TDA portfolio composition from a small set of discrete responses. As can be seen in Figure I, there is much less dispersion along the X-axis that captures TDA portfolio allocations. Such agglomeration of TDA portfolio choices masks important crosssectional heterogeneity that could be used to identify the effects of individual regressors. The 2004 SCF (which is currently in the field) allows much greater detail on TDA portfolio composition, inquiring about a specific percentage of TDA held in equities, as well as about holdings of employer stock. These refined data would be quite helpful in making a stronger empirical case for the effects of precautionary motives on household portfolio choice.

Finally, the bivariate tobit procedure estimates a strong positive correlation for the error terms in the two habitats. One explanation for this is presence of zero-limit (or no-equities) households - unobserved factors that influence household participation decisions in equity markets are likely to work in the same direction in both habitats. For example, households that already incurred the costs of learning about the stock market are more likely to own equities in both accounts. Taken together, the empirical estimates of the determinants of equity shares in the two account types paint a fairly promising picture for our ability to understand observed portfolio allocations in an environment with precautionary savings motives. To the extent these choices represent rational financial decision-making on part of the households, the future with largely self-financed retirements may look somewhat more reassuring.

\section{Conclusion}

Observed portfolio choices in taxable and tax-deferred account habitats are inconsistent with the theoretical predictions of Tepper-Black dual-habitat models. Households commonly fail to exploit the tax advantages of retirement savings plans by choosing to hold high-tax-burden assets like bonds in their taxable accounts, while also maintaining sizable equity positions inside TDAs. However, such behavior may be optimal in an environment that incorporates labor income risk and liquidity restrictions on retirement savings. This paper presents empirical evidence from the SCF that corroborates the hypothesized link between precautionary savings motives and tax-inefficiency of household portfolios. These tests augment the existing empirical literature on portfolio effects of precautionary motives by focusing on account-specific responses to limited liquidity and uninsurable risk. 
This paper also highlights the importance of distinguishing between account habitats in future studies of household financial decision-making. The existing institutional differences in accessibility and tax treatment, as well as distinct savings motives for each of the two account types, may hold the key to resolution of several empirical puzzles. Indeed, there exist dramatic differences in age profiles of equity participation and portfolio composition in the two accounts that can be exploited to identify the reasons for equity non-participation or to assess the degree of responsiveness to various tax incentives like the step-up in basis at death.

The paper also raises a number of unresolved questions. For example, why are not all households that have unrestricted access to their retirement assets tax-efficient? Is relaxation of TDA liquidity restrictions currently debated by Congress likely to improve the quality of household portfolio choices, at least in the narrow sense of tax-efficiency? Given the impending debate on partial privatization of Social Security these questions are likely to remain an important item on the long list of topics in portfolio allocation theory. 


\section{Appendix: Estimation of non-financial income moments from PSID}

The methodology for estimating conditional moments of non-financial income is very similar to Vissing-Jørgensen [2002] and Carroll and Samwick [1998]. The income process of household is a product of a permanent component and a transitory shock: $\mathrm{Y}_{\mathrm{t}}=\mathrm{P}_{\mathrm{t}} \varepsilon_{\mathrm{t}}$, where $\log$ permanent shock follows a random walk with a drift. Switching to log notation, we obtain:

$$
y_{\mathrm{t}}=p_{\mathrm{t}}+\varepsilon_{\mathrm{t}} ; \quad p_{\mathrm{t}}=g_{\mathrm{t}}+p_{\mathrm{t}-1}+u_{\mathrm{t}} ; \quad \mathcal{E}_{\mathrm{t}} \sim \mathrm{N}\left(0, \sigma_{\varepsilon}^{2}\right) ; u_{\mathrm{t}} \sim \mathrm{N}\left(0, \sigma_{\mathrm{u}}^{2}\right),
$$

where both $u_{\mathrm{t}}$ and $\varepsilon_{\mathrm{t}}$ are i.i.d. and are mutually uncorrelated at all leads and lags. The drift term, $g_{\mathrm{t}}$, is predictable on the basis of information available at time $t$ - 1 , i.e. $\mathrm{g}_{t}=\mathrm{f}\left(Z_{\mathrm{t}-1}\right)$.

Differencing of the log income produces:

$$
\begin{aligned}
& y_{\mathrm{t}}-y_{\mathrm{t}-1}=g_{\mathrm{t}}+u_{\mathrm{t}}+\varepsilon_{\mathrm{t}}-\varepsilon_{\mathrm{t}-1} ; \\
& y_{\mathrm{t}}-y_{\mathrm{t}-2}=g_{\mathrm{t}}+g_{\mathrm{t}-1}+u_{\mathrm{t}}+u_{\mathrm{t}-1}+\varepsilon_{\mathrm{t}}-\varepsilon_{\mathrm{t}-2} .
\end{aligned}
$$

The $d$-year conditional variance is then given by $v_{\mathrm{d}}=d \sigma_{\mathrm{u}}{ }^{2}+2 \sigma_{\varepsilon}{ }^{2}$.

In order to remove the predictable drift component, I regress detrended first difference of $\log$ non-financial income on a vector of variables known at time $t-1$ : age of household head, agesquared, occupation and industry dummies, number of children, as well as race, marital, and education category dummies. The resulting residuals are then used to construct sample 1- and 2year conditional variances of labor income for each household: $v_{1}$ and $v_{2}$. With these estimates in hand, one can theoretically separate sample variances of permanent and transitory shock components. However, I do not attempt to do this, using instead an estimate of one-year conditional variance as a regressor.

For estimation I use 1985-1993 PSID data, restricting the sample to households that remained intact over the entire sample period and provided complete responses in each of the survey years. I further exclude households in poverty and Latino subsamples. The resulting sample consists of 2,404 households, each of which has 9 observations. When estimating the predictable component of labor income growth rate, I exclude records which show unemployment spells of more than 4 weeks as well as records with suspiciously low nonfinancial income relative to household sample average $(<10 \%)$. Sample variances are computed for all households, which did not have unemployment spells in any of the 9 sample years. 


\section{References}

Amemiya, Takeshi, “The Estimation of a Simultaneous-Equation Tobit Model," International Economic Review, 20:1 (1979), 169-181.

Ameriks, John, and Stephen P. Zeldes, "How do Household Portfolio Shares Vary with Age?" Working Paper, Columbia University, 2000.

Amromin, Gene, "Household Portfolio Choices in Taxable and Tax-Deferred Accounts: Another Puzzle?” European Finance Review, 7:3 (2003), 547-82.

Banks, James, Richard Blundell, and James P. Smith, "Wealth Portfolios in the U.K. and the U.S,”, Working Paper No.9128, National Bureau of Economic Research, 2002.

Barber, Brad M., and Terrance Odean, “Are Individual Investors Tax Savvy? Evidence from Retail and Discount Brokerage Accounts," Journal of Public Economics, 88:1-2 (2004), 419-42.

Benartzi, Shlomo, "Excessive Extrapolation and the Allocation of 401(k) Accounts to Company Stock," Journal of Finance 56 (2001), 1747-64.

Bergstresser, Daniel, and James Poterba, "Asset Allocation and Asset Location: Household Evidence from the Survey of Consumer Finances," Journal of Public Economics, 88:9-10 (2004), 1893-1915.

Bertaut, Carol, and Michael. Haliassos, "Precautionary Portfolio Behavior from a Life-Cycle Perspective," Journal of Economic Dynamics and Control, 21 (1997), 1511-42.

Black, Fischer, "The Tax Consequences of Long-Run Pension Policy," Financial Analysts Journal, November-December (1980), 13-23.

Carroll, Christopher D., "Buffer Stock Saving and the Life Cycle/Permanent Income Hypothesis," Quarterly Journal of Economics, CXII (1997), 1-55.

Carroll, Christopher D., and Andrew A. Samwick, "How Important is Precautionary Saving?" Review of Economics and Statistics, 80:3 (1998), 410-19.

Carroll Christopher D., Karen E. Dynan, and Spencer S. Krane, "Unemployment Risk and Precautionary Wealth: Evidence from Households' Balance Sheets," Review of Economics and Statistics, 85:3 (2003), 586-604.

Cocco, Joao, Francisco J.Gomes, and Pascal J. Maenhout, "Consumption and Portfolio Choice Over the Life-Cycle," forthcoming The Review of Financial Studies, 2005.

Dammon, Robert M., Chester S. Spatt, and Harold H. Zhang, "Optimal Asset Allocation with Taxable and Tax-Deferred Investing," Journal of Finance, 59:3 (2004), 999-1037. 
Flavin, Marjorie, and Takashi Yamashita, "Owner-Occupied Housing and the Composition of the Household Portfolio over the Lifecycle," American Economic Review, 92:1 (2002), $345-62$.

Gale, William, and Karen M. Pence, "Household Wealth Accumulation in the 1990s: Trends, Determinants, and Implications," mimeo, 2004.

Greene, William, LIMDEP User's Manual (Econometric Software, Inc., 1999).

Guiso, Luigi, Tullio Jappelli, and Daniele Terlizzesse, "Earnings Uncertainty and Precautionary Saving," Journal of Monetary Economics, 30:2 (1992), 307-37.

Hansen, Lars Peter, "Large Sample Properties of Generalized Method of Moments Estimators," Econometrica, 50 (1982), 1029-1054.

Heaton, John and Deborah Lucas, "Market Frictions, Savings Behavior, and Portfolio Choice," Macroeconomic Dynamics, 1 (1997), 76-101.

Heaton, John and Deborah Lucas, "Portfolio Choice in the Presence of Background Risk," The Economic Journal, 110 (2000), 1-26.

Heaton, John and Deborah Lucas, "Asset Pricing and Portfolio Choice: the Importance of Entrepreneurial Risk,” Journal of Finance, 55 (2000), 1163-98.

Hochguertel, Stefan, "Household Portfolio Choices," Unpublished Doctoral Dissertation, Tilburg University, The Netherlands, 1997.

Huang, Jennifer, "Taxable or Tax-Deferred Account? Portfolio Decision with Multiple Investment Goals," mimeo, 2001.

Investment Company Institute, Equity Ownership in America (Washington, DC 1999).

Kimball, Miles, "Precautionary Saving in the Small and in the Large," Econometrica, 58 (1990), 53-73.

Kimball, Miles, “Standard Risk Aversion,” Econometrica, 61 (1993), 589-611.

Liang, Nellie, and Scott Weisbenner, "Investor Behavior and the Purchase of Company Stock in 401k Plans: the Importance of Plan Design," Working Paper No.9131, National Bureau of Economic Research, 2002.

Newey, Whitney K., "Efficient Estimation of Limited Dependent Variable Models with Endogenous Explanatory Variables," Journal of Econometrics, 36 (1987), 231-250. 
Pence, Karen M., "401(k)s and Household Saving: New Evidence from the Survey of Consumer Finances," Working Paper No. 2002-06, Federal Reserve Board, Finance and Economics Discussion Series, 2002a.

Pence, Karen M., "Nature of Nurture: Why do 401(k) Participants save Differently than Other Workers?" Working Paper No. 2002-06, Federal Reserve Board, Finance and Economics Discussion Series, 2002b.

Poterba, James M., and Andrew A. Samwick, "Household Portfolio Allocation over the Life Cycle,” Working Paper No.6185, National Bureau of Economic Research, 1997.

Poterba James M., John B. Shoven, and Clemens Sialm, "Asset Location for Retirement Savers," Working Paper No.7991, National Bureau of Economic Research, 2000.

Shoven, John B., "The Location and Allocation of Assets in Pension and Conventional Savings Accounts," Working Paper No.7007, National Bureau of Economic Research, 1999.

Shoven, John and Clemens Sialm, "Asset Location in Tax-Deferred and Conventional Savings Accounts," Journal of Public Economics 88:1-2 (2004), 23-38.

Tepper, Irving, “Taxation and Corporate Pension Policy,” Journal of Finance 36 (1981), 1-13.

Viceira, Luis M., "Optimal Portfolio Choice for Long-Horizon Investors with Nontradable Labor Income," Journal of Finance, 56:2 (2001), 433-70.

Vissing-Jørgensen, Annette, "Towards an Explanation of Household Portfolio Choice Heterogeneity: Nonfinancial Income and Participation Cost Structures”, mimeo, 2002.

Weisbenner, Scott, "Do Pension Plans with Participant Investment Choice Teach Households to Hold More Equity?” Working Paper No. 1999-61, Federal Reserve Board, Finance and Economics Discussion Series, 1999. 


\section{Table I \\ Classification of Portfolio Allocations by Tax-Efficiency in 1995-2001 Surveys of Consumer Finances}

\begin{tabular}{lcccccc} 
& \multicolumn{2}{c}{$\underline{1995}$} & \multicolumn{2}{c}{$\underline{1998}$} & \multicolumn{2}{c}{$\underline{2001}$} \\
& $\mathrm{~N}$ & $\%$ & $\mathrm{~N}$ & $\%$ & $\mathrm{~N}$ & $\%$ \\
\hline All households (mln.) & 99.0 & & 102.5 & & 106.5 & \\
Positive investable wealth $\mathrm{HHs}^{\mathrm{a}}$ & 32.8 & $33.1 \%$ & 43.6 & $42.6 \%$ & 48.7 & $45.7 \%$ \\
& & & & & & \\
All-bond households: $\{1,0\}$ & 3.0 & $9.2 \%$ & 3.5 & $8.0 \%$ & 4.0 & $8.2 \%$ \\
All-stock households: $\{0,1\}$ & 1.9 & $5.7 \%$ & 1.6 & $3.8 \%$ & 2.1 & $4.3 \%$ \\
Tax-efficient region HHs & 9.2 & $28.1 \%$ & 10.6 & $24.4 \%$ & 10.7 & $21.9 \%$ \\
& & & & & & \\
Tax-inefficient households & 18.7 & $57.0 \%$ & 27.9 & $63.9 \%$ & 31.9 & $65.6 \%$ \\
\hline
\end{tabular}

Source: 1995, 1998, and 2001 Surveys of Consumer Finances
a. Positive investable wealth households are those with investable wealth in both account habitats, as defined in footnote
(a) to Figure 1.
b. Households in the $10 \%$ band around the Tepper-Black tax-efficient frontier, as depicted by the dotted lines in Figure 1. 
Table II

Distribution of Self-Reported Willingness to Take Financial Risks, by Firm Size

Firm Size (number of employees)

\begin{tabular}{lccccc} 
Share responding as: & $<10$ & $10-19$ & $20-99$ & $100-499$ & $>500$ \\
\hline Take very high investment risks & $7.9 \%$ & $5.6 \%$ & $6.9 \%$ & $5.3 \%$ & $5.9 \%$ \\
Take above average risks & $23.2 \%^{* *}$ & $25.1 \%^{*}$ & $27.9 \%$ & $27.4 \%$ & $31.5 \%$ \\
Take average risks & $51.5 \%^{*}$ & $50.5 \%$ & $44.8 \%$ & $48.6 \%$ & $46.1 \%$ \\
Take no risks & $17.3 \%$ & $18.8 \%$ & $20.4 \%$ & $18.7 \%$ & $16.4 \%$ \\
& & & & &
\end{tabular}

Source: 1995, 1998, and 2001 Surveys of Consumer Finances

Note: sample is restricted to households with positive investable wealth in both account types.

* difference of means between a given size category and largest firms (>500) statistically significant at 5\% level

** significant at $1 \%$ level 


\section{Table III \\ Determinants of Location Choice \\ 2-stage Instrumental Variable / AGLS model \\ First-stage regression coeffcients}

dependent variable: share of financial wealth

held in TDA

panel A

panel B

\begin{tabular}{|c|c|c|c|c|c|}
\hline Regressors & Coef. & t-statistic & Coef. & t-statistic & $\begin{array}{l}\text { Eq (1) } \\
\text { group }\end{array}$ \\
\hline Employer match & 0.741 & 9.9 & 0.754 & 7.8 & $I V$ \\
\hline Eligible for $401 \mathrm{k}(1=\mathrm{yes})^{\mathrm{a}}$ & 0.072 & 5.9 & & & \\
\hline Firm size & & & 0.016 & 7.3 & \\
\hline Subject to early withdrawal penalty ( $1=$ yes) & -0.028 & -1.7 & -0.031 & -1.9 & $M$ \\
\hline Financial wealth $^{*}$ & -0.032 & -4.0 & -0.037 & -4.3 & $W$ \\
\hline Housing wealth ${ }^{*}$ & -0.004 & -1.4 & -0.003 & -1.0 & \\
\hline Cond. std. deviation of labor income & -0.211 & -6.9 & -0.146 & -5.6 & $L$ \\
\hline Probability of becoming unemployed & 0.048 & 0.3 & -0.118 & -0.7 & \\
\hline Health care coverage dummy ( $1=$ yes $)$ & -0.013 & -0.8 & -0.013 & -0.8 & \\
\hline Dual earner household dummy (1=yes) & 0.031 & 4.1 & 0.036 & 4.7 & $H$ \\
\hline Precautionary savings household & -0.029 & -3.8 & -0.030 & -4.0 & \\
\hline Enough assets to cover liquidity needs $(1=\mathrm{y})$ & -0.220 & -26.7 & -0.216 & -24.7 & \\
\hline Age of head of household & 0.021 & 10.1 & 0.021 & 10.6 & $D$ \\
\hline Age -squared $\left(* 10^{-2}\right)$ & -0.021 & -9.9 & -0.022 & -10.4 & \\
\hline Education (no high school diploma) & -0.059 & -3.0 & -0.054 & -2.7 & \\
\hline Education (some college) & -0.041 & -3.5 & -0.041 & -3.4 & \\
\hline Education (college or more) & -0.026 & -2.6 & -0.029 & -2.9 & \\
\hline Number of dependents & -0.006 & -2.2 & -0.005 & -1.8 & \\
\hline Availability of DB plan at work & 0.010 & 1.4 & 0.009 & 1.2 & \\
\hline 1995 year dummy & -0.026 & -3.0 & -0.022 & -2.6 & \\
\hline 1998 year dummy & -0.007 & -0.9 & -0.006 & -0.8 & \\
\hline Constant & 0.248 & 5.1 & 0.250 & 5.1 & \\
\hline N (obs.) & 6,476 & & 6,476 & & \\
\hline Measure of fit (adjusted-R ${ }^{2}$ ) & 0.219 & & 0.221 & & \\
\hline
\end{tabular}

* $\gamma$-transformation applied to wealth measures

Source: 1995-2001 Surveys of Consumer Finances

${ }^{a}$ Eligible for any high contribution limit, self-directed retirement plan such as 401k, 403b, Keogh, SEP-IRA, etc. Note: the two panels differ in the choice of an instrumental variable for the endogenous share of wealth invested in TDA. Panel A uses 401k eligibility (and employer contribution match), while panel B uses firm size. 


\section{Table IV \\ Which Households Are Tax-Efficient? \\ 2-SIV/AGLS Probit Model of Tax-Efficient Portfolio Choice \\ Estimates of structural coefficients}

Dependent variable ${ }^{a}: 1$ if household portfolio is "tax-efficient", 0 otherwise

\begin{tabular}{|c|c|c|c|c|}
\hline Regressors & Coef. & t-statistic & Marginal effect ${ }^{\mathrm{D}}$ & $\begin{array}{l}\text { Eq (1) } \\
\text { group }\end{array}$ \\
\hline Share of wealth in TDA & -3.161 & -7.4 & -1.237 & $M$ \\
\hline Subject to early withdrawal penalty ( $1=$ yes) & -0.175 & -2.0 & -0.069 & \\
\hline Financial wealth ${ }^{*}$ & 0.090 & 2.0 & 0.035 & $W$ \\
\hline Housing wealth ${ }^{*}$ & -0.010 & -0.6 & -0.004 & \\
\hline Cond. std. deviation of labor income & -0.419 & -2.7 & -0.164 & $L$ \\
\hline Probability of becoming unemployed & 0.270 & 0.3 & 0.106 & \\
\hline Dual earner household dummy (1=yes) & 0.008 & 0.2 & 0.003 & \\
\hline Health care coverage dummy (1=yes) & -0.064 & -0.8 & -0.025 & $H$ \\
\hline Precautionary savings household & -0.063 & -1.5 & -0.025 & \\
\hline Enough assets to cover liquidity needs $(1=\mathrm{y})$ & -0.612 & -5.9 & -0.239 & \\
\hline Age of head of household & 0.041 & 2.8 & 0.016 & $D$ \\
\hline Age -squared $\left(* 10^{-2}\right)$ & -0.038 & -2.5 & -0.015 & \\
\hline Education (no high school diploma) & -0.126 & -1.1 & -0.049 & \\
\hline Education (some college) & -0.214 & -3.2 & -0.082 & \\
\hline Education (college or more) & -0.144 & -2.6 & -0.056 & \\
\hline Number of dependents & -0.008 & -0.5 & -0.003 & \\
\hline Availability of DB plan at work & -0.065 & -1.7 & -0.026 & \\
\hline 1995 year dummy & 0.098 & 2.1 & 0.039 & \\
\hline 1998 year dummy & 0.024 & 0.6 & 0.009 & \\
\hline Constant & 0.572 & 2.0 & & \\
\hline $\mathrm{N}($ obs.) & 6,469 & & & \\
\hline Measure of fit (pseudo- $\mathrm{R}^{2}$ ) & 0.042 & & & \\
\hline \multicolumn{2}{|l|}{$* \gamma$-transformation applied to wealth measures } & \multicolumn{3}{|c|}{ Source: 1995-2001 Surveys of Consumer Finances } \\
\hline $\begin{array}{l}{ }^{\text {a }} \text { Tax-efficient portfolio is one that contains all } \\
\text { assets are held in taxable accounts (CSA). "L } \\
\text { held directly or through mutual funds, and U. } \\
\text { at least } 90 \% \text { of asset value in each of the acco }\end{array}$ & $\begin{array}{l}\text { tax" asse } \\
\text { " assets } \\
\text { ngs bond } \\
\text { allocate }\end{array}$ & $\begin{array}{l}\text { tax-deferred a } \\
\text { efined here as } \\
\text { portfolio is co } \\
\text { he manner des }\end{array}$ & $\begin{array}{l}\text { unts (TDA), while } \\
\text { ities and municipa } \\
\text { dered to be tax-eff } \\
\text { ed above. }\end{array}$ & $\begin{array}{l}\text { w-tax" } \\
\text { nds } \\
\text { at if }\end{array}$ \\
\hline
\end{tabular}




\section{Table V \\ How Tax-Efficient Are Households? \\ 2-SIV/AGLS Bivariate Tobit Model of Portfolio Choice \\ Estimates of structural coefficients}

Dependent variables: share of an account habitat taxable or TDA) held in equities

Regressors

Share of wealth in TDA

Subject to early withdrawal penalty ( $1=$ yes)

Financial wealth $^{*}$

Housing wealth ${ }^{*}$

Cond. std. deviation of labor income

Probability of becoming unemployed

Dual earner household dummy (1=yes)

Health care coverage dummy (1=yes)

Precautionary savings household

Enough assets to cover liquidity needs $(1=\mathrm{y})$

Age of head of household

Age -squared $\left(* 10^{-2}\right)$

Education (no high school diploma)

Education (some college)

Education (college or more)

Number of dependents

Availability of DB plan at work

1995 year dummy

1998 year dummy

Constant

Correlation $\left(\varepsilon_{\mathrm{CSA}}, \varepsilon_{\mathrm{TDA}}\right)$

$\mathrm{N}$ (obs.)

Nonlimit observations

* $\gamma$-transformation applied to wealth measures
Panel A

$\underline{\text { Taxable portfolio }}$

Coef. t-statistic

$-0.343$

$-0.032$

0.299

0.012

$-0.117$

$-0.570$

0.023

$-0.036$

$-0.039$

0.146

$-0.012$

0.006

$-0.047$

0.025

0.057

0.005

1.0

0.020

0.030

$-0.180$

0.21

6,476

4,914

2.5

1.7

$-3.0$

3.6

1.4

2.2

$-2.1$

7.15
Panel B

Tax-deferred (TDA) portfolio

Coef.

0.506

3.3

0.051

0.133

8.9

0.004

0.8

0.082

1.7

$-0.158$

$-0.6$

0.008

0.5

$-0.055$

$-2.0$

$-0.008$

$-0.6$

0.148

4.0

$-0.014$

$-2.8$

0.006

1.2

0.023

0.7

0.080

3.7

0.080

4.4

0.028

2.2

$-0.095$

$-6.0$

$-0.024$

$-1.6$

0.251

2.6

Note: A tax-efficient household would be expected to hold a higher fraction of its taxable account in equities and a lower fraction of its tax-deferred account (TDA) in equities. Hence, higher values of regressors that have a positive sign in panel A and a negative sign in panel B indicate more tax-efficient portfolio choices. 


\section{Figure I}

\section{Distribution of Portfolio Allocations in TDA and Taxable Accounts in the 2001 Survey of Consumer Finances}

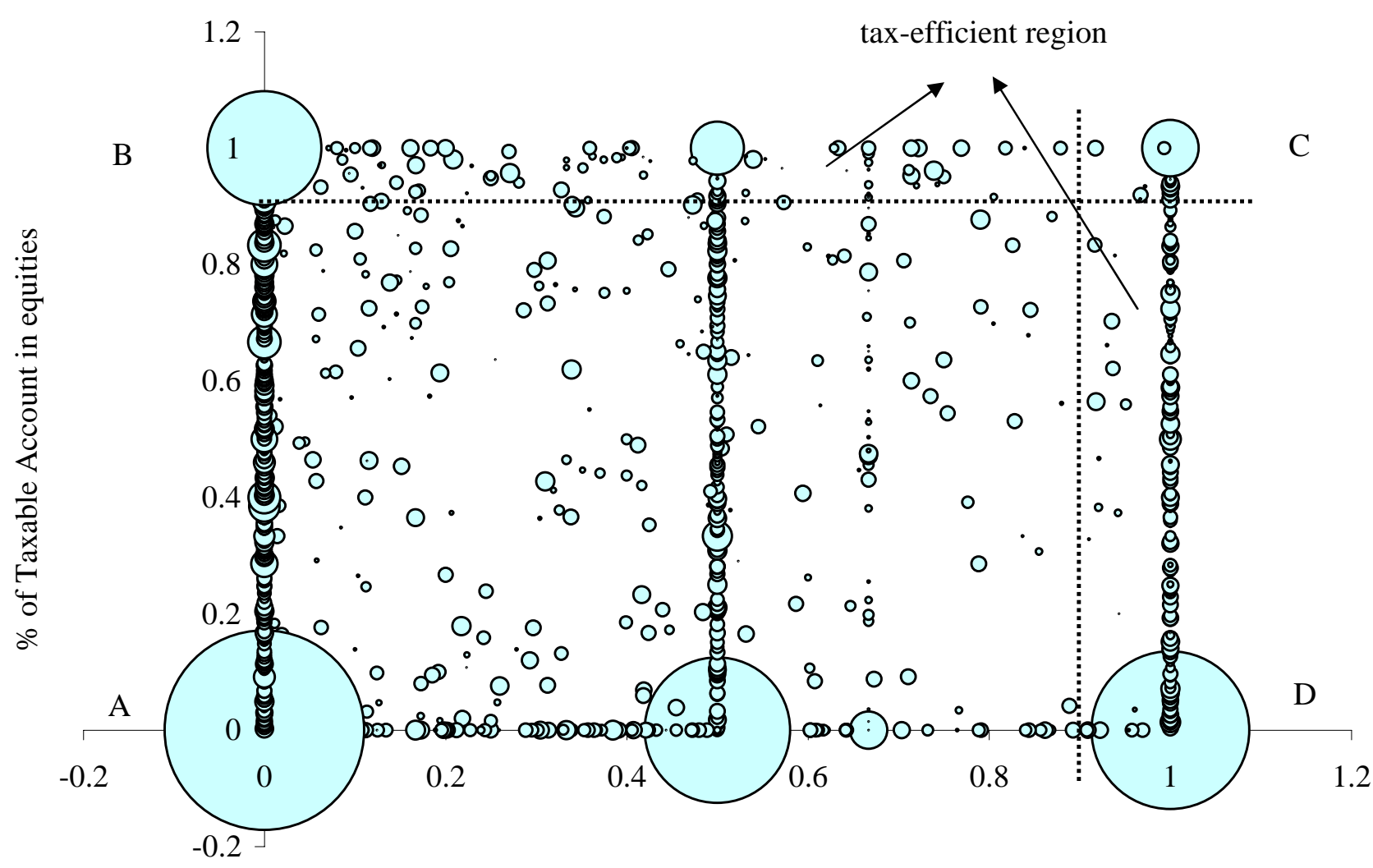

$\%$ of TDA in bonds

a. TDA (tax-deferred account) wealth includes assets in IRA, Keogh, 401k and 403b plans. Investable taxable account wealth excludes checking, but contains almost all other financial assets such as stocks, taxable and tax-exempt bonds, U.S. savings bonds, mutual funds, CDs, and money market accounts. By contrast, Bergstresser and Poterba (2003) also exclude money market and savings accounts from their definition of investable taxable assets. Positive investable wealth households are those with investable wealth in both account habitats.

b. "Equities" in taxable accounts (as well as TDAs) are defined as "low-tax" assets. While this primarily means stocks and stock mutual funds, it also includes other tax-preferred assets such as tax-exempt municipal bonds and U.S. savings bonds. Doing so acknowledges differences in tax treatment of safe and liquid securities and makes the observed lack of tax-efficiency all the more puzzling.

c. Households on the tax-efficient frontier (segments BC and CD) may hold both bonds and stocks in their portfolios. Their "lowtax" assets (as defined in b) are kept in taxable accounts, spilling over into TDA only if their desired bond (or "high-tax") holdings do not exhaust TDA capacity. All other mixed-asset households are tax-inefficient. The tax-efficient region is represented by a $10 \%$ band around this strict definition of Tepper and Black to allow for measurement error. 